\title{
New species in the Hungarian avifauna in 2012
}

\section{TIBOR HADARICS}

Tibor Hadarics 2013. New species in the Hungarian avifauna in 2012. - Ornis Hungarica 21(2): $52-54$.

Abstract A new species appeared in the Hungarian avifauna, the Black-shouldered Kite in 2012. The bird was staying in Fornapuszta (coordinate), near Csákvár (Fejér County), between August $22^{\text {nd }}$ and $27^{\text {th }}$. The number of bird species which occurred in Hungary has risen to 406 with the observation of this species.

Keywords: official bird checklist, Hungarian Checklist and Rarities Committee, Black-shouldered Kite, Elanus caeruleus

Összefoglalás 2012-ben egyetlen faunára új madárfaj bukkant fel Magyarországon, a kuhi. A madár 2012. augusztus 22-27. között a Csákvár (Fejér megye) községhatárában lévő Fornapuszta közelében tartózkodott. E faj megfigyelésével a Magyarországon valaha bizonyítottan előfordult madárfajok száma 406-ra emelkedett.

Kulcsszavak: Magyarország madarainak névjegyzéke, MME Nomenclator Bizottság, kuhi, Elanus caeruleus

Tibor Hadarics, Sopron, Wälder József utca 4. D/2., 9400 Hungary, e-mail: sitke@upcmail.hu

A new bird species in the fauna of Hungary was accepted by the Hungarian Checklist and Rarities Committee in 2012; the Black-shouldered Kite (Klébert 2012). The number of bird species which occurred in Hungary has risen to 406 with the observation of this species.

Elanus caeruleus (Desfontaines, 1789) Black-shouldered Kite

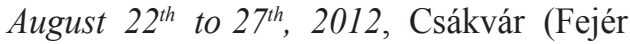
County), Fornapuszta, near Lake Csukás, 1 ad. exemplar (G. Szalai and others).

The Black-shouldered Kite is a small, grey plumaged bird of prey in the family Accipitridae. It's generally distributed in Sub-Saharan Africa, (ssp. caeruleus), in India, Indo-China and the Malay Peninsula (ssp. vociferus), as well as in the South-east Asian archipelago (ssp. hypoleucus), and in
New Guinea (ssp. wahgiensis) (del Hoyo et al. 1994).

The species also breeds in North Africa (ssp. caeruleus), and since the last third of the past century in Southwestern Europe as well, in growing numbers (Rufino 1997). It first nested in Portugal in 1944 (England 1955), in Spain in 1975, and in Souther France in 1983 (Papacotsia \& Petit 1984, Guyot 1990, Ferguson-Lees \& Christie 2001). The European breeding population showed a strong increasing trend between 1970 and 1990. The pace of the increase slowed down between 1990 and 2000. Around the turn of the millennium the European population was already estimated to be between 810 and 2000 pairs (Spain, Portugal and France) (BirdLife International 2004). The population of four pairs gradually grew to 28 pairs by 2008 (de Seynes 2009) in France. Similarly to its spread and 
population growth in Southwestern Europe the species is also expanding in the Middle East (ssp. vociferus): it first bred in Iran in 1998, in Iraq in the beginning of the 2000s (Salim 2002), in Israel in 2011 (Israeli 2012). The spatial distribution of the species will expectedly grow further as a result of climate change (Huntley et al. 2007).

Previously its occurrences outside of its nesting period were known in Southern Europe (Italy, Cyprus) (del Hoyo et al. 1994), but in recent decades also in the Netherlands, Belgium, Germany, the Czech Republic, Switzerland, Austria and Poland, moreover they were observed on several occasions in Scandinavia - Denmark, Sweden - which beyond the increase in the number of observers, was probably a result of the expansion and growth of the Southwestern European population.

Late spring observations (May) in Northern and Central Europe are probably of individuals dragged North by Mediterranean cyclones, while summer occurrences undoubtedly after the breeding period, can be connected to individuals dispersing towards the north and north-east.

The bird in Hungary was first observed by Gábor Szalai on August 22 $2^{\text {nd }}, 2012$, in the late afternoon in the Zámoly Basin, near Fornapuszta located in the municipal boundary of Csákvár. The bird was seen on every one of the five days following its initial observation (last on August 27 $7^{\text {th }}$ ) in the same area. During this period several evidentiary photos were taken of the individ- ual. The bird was identified to be in adult plumage.

At the time of the observation and in the preceding period warm southwestern air currents had caused sweltering heat lasting for several days in the Carpathian Basin. It's probable, that the bird had arrived in Central Europe with these warm air currents coming from the south-west.

A week prior to the Csákvár observation, on August 15 $5^{\text {th }}$ 2012, a Black-shouldered Kite was also seen and photographed near Maňa in Slovakia (Václav 2013). This was the first recorded sighting of the species in Slovakia as well. The question arises, if at the occurrence of the Hungarian and Slovakian observations the same individual was sighted? Only one week passed between the two observations and the two locations are 90 to 100 kilometers from each other. It is plausible that the same individual was seen in Slovakia as well as in Hungary, however observers have pointed out minor differences in plumage of the two birds: while the individual in Hungary is regarded as a full adult, the Slovakian bird, based on its moulting is considered to be a subadult.

\section{Acknowledgements}

I would like to express my gratitude to referees and Dániel Paizs and Péter Fehérvári, who made the language correction for the manuscript. 


\section{References}

BirdLife International 2004. Birds in Europe. Population estimates, trends and conservation status. BirdLife International, Cambridge

del Hoyo, J., Elliott, A. \& Sargatal, J. 1994. Handbook of the birds of the World. Vol. 2. New World vultures to guineafowl. - Lynx Edicions, Barcelona p. 115.

England, M. D. 1955. Observations on the Blackwinged Kite in Portugal, with preliminary notes on its status. - British Birds 56(12): 444-452.

Ferguson-Lees, J. \& Christie, D. 2001. Raptors of the World. - Christopher Helm, London pp. 355-358.

Guyot, A. 1990. Première nidification réussie en France de 1'Elanion blanc. - Nos Oiseaux 40: 465-477.

Huntley, B., Green, R. E., Collingham, Y. C. \& Willis, S. G. 2007. A climatic atlas of European breeding birds. - Durham University, RSPB, Lynx Edicions, Barcelona p. 101.

Israeli, N. 2012. The first breeding record of the Black-shouldered Kite in Israel. - A Bird's Eye
View of the Holy Land (Newsletter from Israel) 11: 8 .

Klébert, A. 2012. Új faj Magyarországon! [New species in Hungary!] - Cincér 8(3): 2. (in Hungarian)

Papacotsia, A. \& Petit, P. 1984. Présence d'un couple d'Elanions blancs Elanus caeruleus en Aquitanie. - Le Courbageot 10: 19-24.

Rufino, R. 1997. Elanus caeruleus Black-winged Kite. - In: The EBCC atlas of European breeding birds. Their distribution and abundance. - T \& AD Poyser, London p. 153.

Salim, M. A. 2002. The first records, including breeding, of Black-winged Kite Elanus caeruleus in Iraq. - Sandgrouse 24(2): 136-138.

de Seynes, A. 2009. Les oiseaux nicheurs rares et menacés en France en 2008. - Ornithos 16(3): 153184.

Václav, R. 2013. First observation of the Blackwinged Kite Elanus caeruleus in Slovakia. - Slovak Raptor Journal 6(1): 27-30.

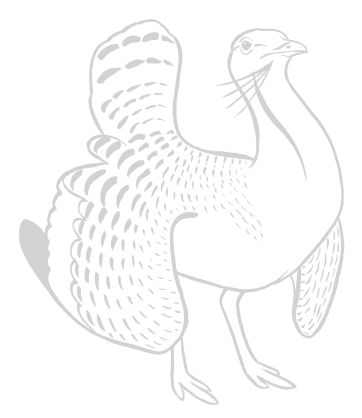

